\title{
Genetic analyses, phenotypic adaptability and stability in sugarcane genotypes for commercial cultivation in Pernambuco
}

\author{
J.A. Dutra Filho'; T.C. Junior ${ }^{2}$ and D.E. Simões Neto ${ }^{3}$ \\ ${ }^{1}$ Unidade Acadêmica de Ciências Agrárias (Campus Pombal), \\ Universidade Federal de Campina Grande, Pombal, PB, Brasil \\ ${ }^{2}$ Departamento de Genética, Universidade Federal de Pernambuco, Recife, PE, \\ Brasil \\ ${ }^{3}$ Estação Experimental de Cana-de-açúcar do Carpina, \\ Universidade Federal Rural de Pernambuco, Recife, PE, Brasil
}

Corresponding author: J.A. Dutra Filho

E-mail: filho-dutra@ig.com.br

Genet. Mol. Res. 14 (4): 12102-12110 (2015)

Received February 6, 2015

Accepted July 10, 2015

Published October 5, 2015

DOI http://dx.doi.org/10.4238/2015.October.5.23

ABSTRACT. In the present study, we assessed the agro-industrial performance of 22 sugarcane genotypes adaptable to edaphoclimatic conditions in production microregions in the State of Pernambuco, Brazil, and we recommended the commercial cultivation of select genotypes. The variables analyzed were as follows: sucrose percentage in cane juice, tonnage of saccharose per hectare (TPH), sugarcane tonnage per hectare (TCH), fiber, solid soluble contents, total recoverable sugar tonnage (ATR), and total recoverable sugar tonnage per hectare (ATR $t / h a)$. A randomized block design with 4 repeats was used. Combined variance of the experiments, genetic parameter estimates, and environment stratification were analyzed. Phenotypic adaptability and stability were analyzed using the Annicchiarico and Wricke methods and analysis of variance. Genetic gain was estimated using the classic index and sum of ranks. Genotype selection was efficient for TPH, TCH, and ATR t/ha. Genotypes presented 
a great potential for improvement and a similar response pattern in Litoral Norte and Mata Sul microregions for TPH and TCH and Litoral Norte and Litoral Sul microregions for ATR t/ha. Genotypes SP78-4764, RB813804, and SP79-101 showed better productivity and phenotypic adaptability and stability, according to the Wricke and Annicchiarico methods. These genotypes can be recommended for cultivation in the sugarcane belt in the State of Pernambuco.

Key words: Genetics parameters; Genetic gain; Plant improvement; Saccharum spp

\section{INTRODUCTION}

Sugarcane is a crop of great economic relevance, and it contributes to approximately $2 \%$ of the gross domestic product of Brazil (BIOSEV, 2013). Brazil is the largest sugarcane producer in the world, and it produced more than 653 million tons of sugarcane in $2013 / 2014$. The country also ranks first in sugar production, with a $25 \%$ global share, and it is responsible for $50 \%$ of the world's sugar export (UNICA, 2013).

The State of Pernambuco, in the northeast region of Brazil, stands out in the Brazilian economic scenario, as it produces 15.07 million tons of sugarcane for the sugar and alcohol industries, and is the second-largest producer of sugarcane in Brazil (CONAB, 2013). However, mean productivity is relatively low, with roughly 45 tons of sugarcane per hectare. The main reason that hampers improvements in sugarcane productivity is the interaction between sugarcane genotype and the environment, expressed mainly as diversity in soil characteristics, sloped terrains and irregular rainfall patterns, as long periods of drought are common in the region.

Koffler et al. (1986) characterized the sugarcane belt in Pernambuco. They rated Mata Norte, Mata Sul (MS), Região Central, Litoral Norte (LN), and Litoral Sul (LS). For each microregion, the geology, geomorphology, climate, hydrology, natural vegetation, soil, and ecological zoning were characterized. They concluded that the agro-industrial performance of a given cultivar in one microregion could not be reproduced in another microregion. In addition, they reported that the environment may facilitate or obstruct the expression of particular characteristics of economic interest. According to Bressiani et al. (2002), when the genotype-environment interaction is too robust, selection of superior cultivars is difficult. Therefore, it is clear that the development of new cultivars with excellent potential that respond advantageously to environmental improvements (i.e., adaptability) and with only slight variations in overall behavior when exposed to a different environmental setting (stability) is essential for any strategy developed to increase sugarcane production in Pernambuco. According to Dutra Filho et al. (2013), several studies have addressed the genotype-environment interaction and phenotype adaptability and stability in sugarcane. These efforts, such as the relevant investigations conducted by Rea and Souza-Vieira (2002), Kumar et al. (2004), and Bastos et al. (2007), to mention a few, attempt to shed more light on productivity improvement based on the selection of superior sugarcane cultivars.

The aim of the present study was to evaluate the agro-industrial performance, genetic parameters, and genetic gain of new sugarcane genotypes and select the genotypes that were most adaptable to edaphoclimatic conditions in the sugarcane microregions of the State of Pernambuco, Brazil. 


\section{MATERIAL AND METHODS}

The experiments were performed in the cultivation areas of sugarcane processing plants taking part in the sugarcane genetic improvement program (Programa de Melhoramento Genético da Cana-de-açúcar) of Universidade Federal Rural de Pernambuco. The program is part of a university network established to promote the development of the sugar and alcohol sectors [Rede Interuniversitáriapara o Desenvolvimento do Setor Sucroenergético (PMGCA/UFRPE/RIDESA)]. The sugar mills used were Usina Santa Tereza, Usina Trapiche, and Usina Pumaty, and they represented the LN, LS, and MS microregions, respectively, in accordance with the classification proposed by Koffler et al. (1986). Experimental data were obtained using samples collected as of two moments in the sugarcane production cycle, adult plant, and sprout after the first harvest.

The following genotypes were analyzed: RB813804, RB863129, RB962545, RB962560, RB962659, RB962660, RB962977, RB962882, RB962943, RB962962, RB962975, RB972773, SP78-4764, SP79-1011, RB962602, RB962628, RB962790, RB962806, RB962812, RB962920, RB962965, and RB963240. A randomized block design with 4 repeats was used. Experimental parcels were defined as a set of five $8-\mathrm{m}$ rows interspaced by $1-\mathrm{m}$ passages. Plantations were grown according to the traditional method. Soil $\mathrm{pH}$ corrections and fertilization techniques were performed following the system adopted by each agro-industrial company.

The variables analyzed were as follows: sucrose percentage in cane juice (POL\%), tonnage of saccharose per hectare $(T P H)$, sugarcane tonnage per hectare $(T C H)$, fiber, solid soluble contents, total recoverable sugar tonnage (ATR), and total recoverable sugar tonnage per hectare (ATR t/ha). For the estimation of TPH, TCH, and ATR $t /$ ha, the methods described by Dutra Filho et al. (2013) were used. Fiber (FIB), corrected POL (PCC), and ATR were calculated according to the method reported by Fernandes (2003). Multiple-factor analysis of variance was used for the experiments and genetic parameter estimates (Cruz, 2006). Means were clustered using the Scott and Knott (1974) test at 5\% probability. The environments were stratified according to the method reported by Cruz et al. (2012). Analysis of variance (ANOVA) and methods developed by Wricke (1965) and Annichiarico (1992) were used to analyze phenotype adaptability and stability. All data were processed using the GENES program (Cruz, 2006).

\section{RESULTS}

On the basis of the variance analysis for the experiments, significant differences in TPH, $\mathrm{TCH}$, and ATR t/ha were observed for all genotypes evaluated in the microregions LN, LS, and MS (Table 1). Significant differences were detected for all variables with respect to the harvest cycles considered. With respect to genotype $\mathrm{x}$ harvest cycles, significant differences were observed in the LN microregion for all the variables, except FIB. In the LS microregion, significant differences were found for TPH, TCH, and ATR t/ha, and, in the MS microregion, significant differences were detected for FIB, PCC, solid soluble contents, and ATR.

Means clustering (Scott and Knott, 1974) (Table 2) allowed the placement of genotypes that performed better in superior groups. In the LN microregion, genotypes SP78-4764, SP791011, RB962962, RB863129, RB962560, RB962675, and RB962877 clustered and formed group "a" for variables TPH, TCH, and ATR t/ha. In the LS microregion, genotypes SP78-4764, RB813804, RB963043, RB962687, SP81-3250, RB963085, SP79-1011, RB962943, RB963193, RB963086, RB963094, RB963034, and RB962545 clustered and formed group "a" for TCH. In the MS microregion, genotypes SP78-4764, SP79-1011, RB962902, RB962965, RB813804, and RB963240 clustered and formed group "a" for ATR t/ha. 


\begin{tabular}{|c|c|c|c|c|c|c|c|c|}
\hline \multirow[t]{2}{*}{ Environment } & \multirow[t]{2}{*}{ Variable } & \multicolumn{3}{|c|}{ Mean Squares } & \multirow[t]{2}{*}{ Residuals } & \multirow[t]{2}{*}{ Mean } & \multirow[t]{2}{*}{ CV (\%) } & \multirow[t]{2}{*}{$\mathrm{H}$} \\
\hline & & Genotype & Cuts & $G \times C$ & & & & \\
\hline \multirow[t]{7}{*}{$\overline{\mathrm{LN}}$} & TPH & $14.69^{* *}$ & $128.30^{* \star}$ & $5.45^{\star \star}$ & 0.86 & 5.59 & 16.56 & 1.37 \\
\hline & $\mathrm{TCH}$ & $735.88^{\star \star}$ & $7802.51^{\star \star}$ & $178.59^{\star *}$ & 37.06 & 41.97 & 14.50 & 1.43 \\
\hline & FIB & $1.99^{*}$ & $14.51^{\star \star}$ & $0.89^{\text {ns }}$ & 0.65 & 14.52 & 5.55 & 1.76 \\
\hline & PCC & $2.44^{\mathrm{ns}}$ & $16.68^{\star \star}$ & $2.72^{\star \star}$ & 0.71 & 13.34 & 6.35 & 3.87 \\
\hline & BRIX & $2.63^{\text {ns }}$ & $51.62^{\star \star}$ & $2.69^{\star *}$ & 0.75 & 18.98 & 4.55 & 3.29 \\
\hline & ATR & $272.22^{\text {ns }}$ & $1509.17^{\star *}$ & $287.83^{\star *}$ & 85.63 & 136.11 & 6.78 & 4.18 \\
\hline & ATR t/ha & $14.27^{*}$ & $142.36^{\star *}$ & $5.28^{\star *}$ & 0.95 & 5.72 & 5.72 & 1.47 \\
\hline \multirow[t]{7}{*}{ LS } & TPH & $25.65^{*}$ & $300.60^{\star \star}$ & $10.70^{\star *}$ & 5.17 & 13.63 & 16.69 & 1.11 \\
\hline & $\mathrm{TCH}$ & $1018.5^{\star *}$ & $64897.6^{\star *}$ & $353.96^{\star \star}$ & 197.31 & 103.80 & 13.53 & 1.28 \\
\hline & FIB & $2.42^{\text {ns }}$ & $21.27^{\star \star}$ & $3.14^{\mathrm{ns}}$ & 2.17 & 13.74 & 10.72 & 8.95 \\
\hline & PCC & $2.60^{\text {ns }}$ & $225.38^{\star *}$ & $2.44^{\text {ns }}$ & 1.70 & 13.51 & 9.67 & 19.1 \\
\hline & BRIX & $2.29^{\mathrm{ns}}$ & $301.20^{\star \star}$ & $2.22^{\mathrm{ns}}$ & 1.50 & 19.33 & 6.33 & 7.10 \\
\hline & ATR & $243.89^{\text {ns }}$ & $19922.0^{* *}$ & $158.95^{\mathrm{ns}}$ & 158.95 & 135.87 & 9.27 & 18.9 \\
\hline & ATR t/ha & $25.23^{*}$ & $381.53^{\star \star}$ & $10.23^{\star *}$ & 5.11 & 13.76 & 16.42 & 1.22 \\
\hline \multirow[t]{7}{*}{ MS } & TPH & $32.35^{\star \star}$ & $344.93^{\star *}$ & $7.31^{\mathrm{ns}}$ & 5.44 & 11.96 & 19.49 & 5.25 \\
\hline & $\mathrm{TCH}$ & $1227.1^{\star *}$ & $19867.5^{\star \star}$ & $250.68^{\text {ns }}$ & 221.55 & 81.62 & 18.23 & 5.12 \\
\hline & FIB & $4.54^{\mathrm{ns}}$ & $103.90^{* *}$ & $3.68^{\star *}$ & 0.83 & 14.91 & 6.13 & 5.53 \\
\hline & PCC & $1.11^{\mathrm{ns}}$ & $48.37^{\star \star}$ & $3.68^{* *}$ & 1.81 & 14.78 & 9.10 & 7.90 \\
\hline & BRIX & $3.80^{\mathrm{ns}}$ & $69.05^{\star \star}$ & $3.39^{\star *}$ & 2.48 & 20.07 & 7.85 & 7.48 \\
\hline & ATR & $205.78^{\text {ns }}$ & $4509.64^{* *}$ & $256.60^{* *}$ & 88.07 & 147.85 & 6.34 & 3.54 \\
\hline & ATR t/ha & $34.24^{\star \star}$ & $341.68^{\star \star}$ & $7.22^{\mathrm{ns}}$ & 5.01 & 11.98 & 18.68 & 3.24 \\
\hline
\end{tabular}

LN: Litoral Norte, LS: Litoral Sul, and MS: Mata Sul; G x C: Interaction between genotype and environment; H: Hartley $\mathrm{F}$ test; $\mathrm{TPH}=$ tonnage of sacchorose per hectare; $\mathrm{TCH}=$ sugarcane tonnage per hectare; FIB = fiber; adjusted POL\% $(\mathrm{PCC}), \mathrm{BRIX}=$ solid soluble contents; ATR = total recoverable sugar tonnage; and ATR tha = total recoverable sugar tonnage per hectare.

Regarding the estimated genetic parameters (Table 3), the heritability coefficient was of average magnitude for the variables TPH, TCH, and ATR t/ha in the LN and LS microregions. However, this coefficient was of a higher magnitude for these variables in the MS microregion.

Environment stratification (Table 4) revealed the similarity pattern in the genotypes' response to the LN and MS microregions for TPH and TCH and to the LN and LS microregions for ATR tha.

According to the methods for classical selection index and sum of ranks, the highest genetic gains will be obtained via selection based on $\mathrm{TCH}$, which is used to estimate TPH and ATR t/ha (Table 5).

Table 6 presents phenotype adaptability and stability for TPH, TCH, and ATR t/ha by using the Wricke method. Genotypes RB813804 and SP79-1011 showed higher stability for TPH and TCH, and genotypes RB813804, RB962545, and SP78-4764 showed high stability for ATR t/ha, suggesting commercial cultivation for these genotypes in any of the considered environments.

The method used by Annichiarico (1992) showed that the LN microregion was unfavorable and the LS microregion was favorable to variables TPH, TCH, and ATR t/ha (Table 7).

On the basis of these considerations, it was concluded that genotype SP78-4764 exhibited a higher general adaptability for TPH and can be recommended for cultivation in the 3 surveyed environments (Table 8). Genotypes RB813804 and SP78-4764 presented specific adaptability to favorable environments LS and MS (Table 8). Genotype SP78-4764 exhibited a higher general adaptability for TCH. Genotypes SP78-4764 and SP79-1011 presented specific adaptability to unfavorable environments LN and MS (Table 7). Genotypes SP78-4764 and SP79-1011 exhibited a higher general adaptability for ATR t/ha. Genotypes SP78-4764 and SP79-1011 presented a specific adaptability to favorable environments LS and MS (Table 7). 


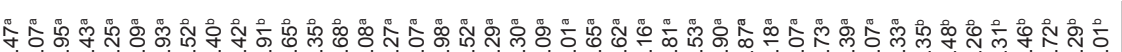

妥

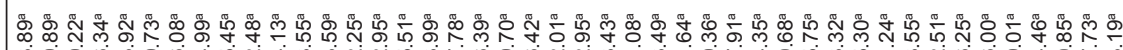

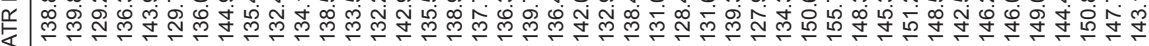

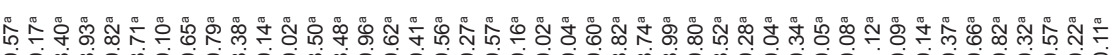

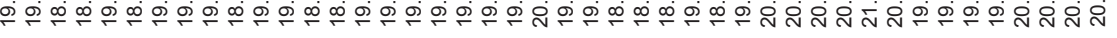

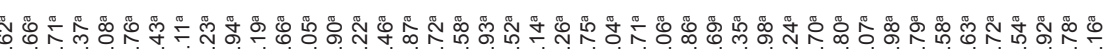

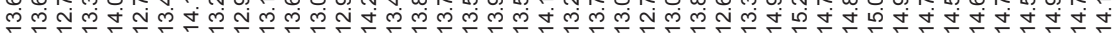

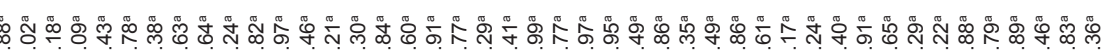

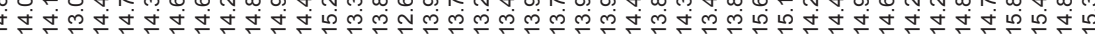

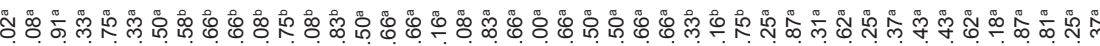

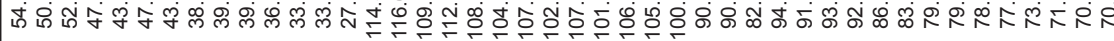

吾

în.

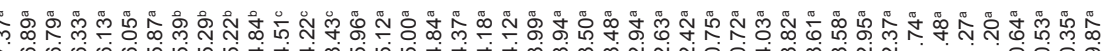


Table 3. Estimated genetic parameters for the characters evaluated in sugarcane microregionsin the State of Pernambuco, Brazil.

\begin{tabular}{|c|c|c|c|c|c|c|}
\hline \multirow[t]{2}{*}{ Environment } & \multirow[t]{2}{*}{ Variable } & \multicolumn{5}{|c|}{ Genetic parameters } \\
\hline & & $\varphi_{\mathrm{g}}^{2}$ & $\hat{\sigma}_{\mathrm{gc}}^{2}$ & $\mathrm{H}^{2}$ & $\mathrm{CVg}$ & $\overline{\mathrm{CVg} / \mathrm{CVe}}$ \\
\hline \multirow[t]{7}{*}{$\mathrm{LN}$} & TPH & 0.76 & 1.06 & 63 & 15.67 & 0.95 \\
\hline & $\mathrm{TCH}$ & 46.44 & 32.85 & 76 & 16.23 & 1.11 \\
\hline & FIB & 0.09 & 0.05 & 55 & 2.08 & 0.38 \\
\hline & PCC & 0.00 & 0.46 & 00 & 0.00 & 0.00 \\
\hline & BRIX & 0.00 & 0.45 & 00 & 0.00 & 0.00 \\
\hline & ATR & 0.00 & 0.46 & 00 & 0.00 & 0.00 \\
\hline & ATR t/ha & 0.75 & 1.00 & 63 & 15.10 & 0.89 \\
\hline \multirow[t]{7}{*}{ LS } & TPH & 1.24 & 1.29 & 58 & 8.19 & 0.49 \\
\hline & $\mathrm{TCH}$ & 55.38 & 36.71 & 65 & 7.16 & 0.52 \\
\hline & FIB & 0.00 & 0.22 & 0 & 0.00 & 0.00 \\
\hline & PCC & 0.01 & 0.17 & 6 & 0.86 & 0.08 \\
\hline & BRIX & 0.00 & 0.16 & 3 & 0.37 & 0.00 \\
\hline & ATR & 1.24 & 16.40 & 6 & 0.82 & 0.08 \\
\hline & ATR t/ha & 1.24 & 1.20 & 59 & 0.49 & 0.49 \\
\hline \multirow[t]{7}{*}{ MS } & $\mathrm{TPH}$ & 1.56 & 0.43 & 77 & 10.45 & 0.53 \\
\hline & $\mathrm{TCH}$ & 61.02 & 6.76 & 80 & 9.57 & 0.52 \\
\hline & FIB & 0.05 & 0.66 & 18 & 1.55 & 0.25 \\
\hline & PCC & 0.00 & 0.43 & 0 & 0.00 & 0.00 \\
\hline & BRIX & 0.02 & 0.21 & 11 & 0.79 & 0.10 \\
\hline & ATR & 0.00 & 39.12 & 0 & 0.00 & 0.00 \\
\hline & ATR t/ha & 1.68 & 0.51 & 79 & 10.84 & 0.58 \\
\hline
\end{tabular}

$\varphi_{\mathrm{g}}^{2}$ : Genetic variance component: $\hat{\sigma}_{g c}^{2}$ genotype-environment interaction variance component $\mathrm{H}^{2}$ : genotypical determination as mean $\mathrm{CVg}$ : Genetic coefficient variation $\mathrm{CVg} / \mathrm{CVe}$ : $\mathrm{b}$ index.

Table 4. Stratification of sugarcane microregions in the state of Pernambuco, Brazil, on the basis of the similarity pattern of the response of genotypes to each environment.

\begin{tabular}{lrcrr}
\hline Variable & QMI/r & F calculated & F tabulated $(5 \%)$ & Environment \\
\hline TPH & 0.97 & 1.47 & 2.94 & 1 and 3 \\
TCH & 32.77 & 1.38 & 2.94 & 1 and 3 \\
ATRtha & 0.85 & 1.18 & 2.94 & 1 and 2
\end{tabular}

1: Litoral Norte; 2: Litoral Sul; and 3: Mata Sul.

Table 5. Estimated selection gain for variable TCH in sugarcane genotypes evaluated in sugarcane microregions in the State of Pernambuco, Brazil.

\begin{tabular}{lccc}
\hline Selection gain & TCH $(\mathrm{LN})$ & TCH $(\mathrm{LS})$ & TCH (MS) \\
\hline Classical & 12.24 & 5.63 & 9.79 \\
Sum of ranks & 13.08 & 5.28 & 9.80
\end{tabular}

LN: Litoral Norte, LS: Litoral Sul; and MS: Mata Sul.

Table 6. General adaptability (Wi) estimates by using the Wircke method (1965) for the variables TPH, TCH, and ATR $t /$ ha in sugarcane microregionsin the State of Pernambuco, Brazil.

\begin{tabular}{lccc}
\hline Genotype & & Variables/Adaptability & ATR t/ha Wi (\%) \\
\cline { 2 - 4 } & TPH/Wi (\%) & TCH/Wi (\%) & 30.83 \\
\hline RB813804 & 30.14 & 26.71 & 30.82 \\
RB962545 & 25.59 & 23.46 & 10.74 \\
SP78-4764 & 13.35 & 8.43 & 27.59 \\
SP79-1011 & 30.90 & 40.98 & \\
\hline
\end{tabular}


Table 7. Classification of sugarcane microregions in the State of Pernambuco, Brazil, according to Annichiarico (1992).

\begin{tabular}{llrrr}
\hline Microregions & Variable & Mean & Index & Class \\
\hline Litoral Norte & TPH & 7.26 & -4.57 & Unfavorable \\
& TCH & 55.43 & -40.60 & Unfavorable \\
LitoralSul & ATRt/ha & 7.53 & -4.65 & Unfavorable \\
& TPH & 15.49 & 3.65 & Favorable \\
& TCH & 141.43 & 45.39 & Favorable \\
Mata Sul & ATRt/ha & 15.86 & 3.68 & Favorable \\
& TPH & 12.76 & 0.92 & Favorable \\
& TCH & 91.25 & -4.79 & Unfavorable \\
& ATRt/ha & 13.15 & 0.97 & Favorable \\
\hline
\end{tabular}

Table 8. General adaptability Wi estimates $(\mathrm{g})$ for favorable Wi(+) and unfavorable Wi(-) environments, according to Annichiarico (1992), for the variables TPH, TCH, and ATR t/ha in sugarcane genotypes evaluated in sugarcane microregionsin the State of Pernambuco, Brazil.

\begin{tabular}{lccccrr}
\hline Genotype & \multicolumn{5}{c}{ Variables/adaptability } \\
\cline { 2 - 7 } & TPH/Wi(g) & TPH/Wi(+) & TCH/Wi(g) & TCH/Wi(-) & ATR t/ha/Wi(+) & ATR t/ha/Wi(-) \\
\hline RB813804 & 91.93 & 97.77 & 93.75 & 90.26 & 92.12 & 98.16 \\
RB962545 & 66.15 & 72.55 & 74.28 & 68.11 & 68.19 & 72.49 \\
SP78-4764 & 129.84 & 125.69 & 119.67 & 125.91 & 128.66 & 125.23 \\
SP79-1011 & 98.82 & 94.21 & 99.10 & 103.64 & 98.78 & 94.48 \\
\hline
\end{tabular}

\section{DISCUSSION}

Results of the variance analysis show the occurrence of genetic variability across the evaluated genotypes on the basis of variables that, according to Bastos et al. (2003), are among the most important elements in sugarcane production. For the source of variation in harvest cycle, Rosse et al. (2002), pointed out that these differences as a consequence of adverse climatic factors exert an influence on the expression of the considered variables. According to Silva (2008), the significant interaction between genotype and harvest cycle is the result of the distinctive manner in which genotypes react in different environments. This provides breeders an opportunity to select superior genetic materials that have only a few variations in productivity with respect to sugarcane and sugarcane ratoon (Neto et al., 2012). Souza et al. (2012) obtained similar results when they evaluated the agro-industrial performance of commercial sugarcane cultivars in the Mata Centro microregion of Pernambuco, and they identified genotypes with the highest productivity in three harvest cycles.

According to Dutra Filho et al. (2011), when the values of genetic variance are high in relation to the interaction between genotype and harvest cycle variance or the interaction between genotype and environment variance, along with a high heritability coefficient, a very favorable situation is indicated for breeding, i.e., expression of the characters used in the selection process is mostly due to genetic effects, and not the environment. This shows the greater reliability of phenotypic values as indicators for genetic values that favor the selection process. In the present study, this fact has not been completely verified (Table 3). For example, genetic variance was superior for genotype $x$ harvest cycle variance in the three microregions for $\mathrm{TCH}$. Genotype $\mathrm{x}$ harvest cycle variance was greater than genetic variance in the LN and LS microregions for TPH, and the heritability coefficients showed an average magnitude. Indeed, with the heritability of average magnitude and discrimination of the genotypes by the average testing used, the breeder 
can identify, with a certain safety margin, the genotypes to be grown in the evaluated environments. However, as the interaction between genotype and harvest circle variance was significant and the genotypes presented in a distinctive manner in different environments, it is important to observe that there are common genotypes in the environments considered to realize statistical analysis more elaborate to verify the nature of interactions and identify genotypes adapted to the climatic conditions in question. In the present study, the genotypes RB813804, RB962545, SP78-4764, and SP79-1011 were used in the environment stratification and adaptability and stability analyses.

As a general rule, commercial planting of the evaluated genotypes is performed in the 2 most homogeneous microregions (Table 4). According to Oliveira et al. (2004), environments should be chosen on the basis of the specific needs defined in cultivation programs. They state that criteria such as availability of research centers, easy access, and relevance of production centers (microregions) should be adopted. This also reveals the need for phenotype adaptability and stability analyses so as to identify genotypes adaptable to other microregions.

It is important to emphasize that the phenotypic adaptability and stability analyses should be performed on the basis of TPH, TCH, and ATR t/ha because, according to the methods for classical selection index and sum of ranks, the highest genetic gain will be obtained via selection based on $\mathrm{TCH}$, which is used to estimate the abovementioned variables (Table 5).

However, one of the limitations of the adaptability and stability analysis by using the Wricke method, according Cruz et al. (2012), is the vagueness of the stability parameter due to the lack of information of the considered environments with no direction of response of the genotypes to specifics environmental (Cruz et al., 2012).

Although it can be applied to a limited number of environments, the Wricke method (1965) quantifies only the relative contribution of each genotype to the interaction between genotype and environment and identifies the most stable genotype; thus, it is important to use other methods to collate information on the magnitude of the interactions.

According to Amorim et al. (2006), the method proposed by Annicchiarico (1992) considers that an ideal genotype has the highest mean percentage and the highest recommendation index. By using this method, it is possible to classify sugarcane microregions on the basis of favorable and unfavorable environments (Table 7).

Silva et al. (2004) concluded that the method developed by Annicchiarico (1992) is among the best, since it includes, under one parameter, the concepts of adaptability and stability, which makes result interpretation easier.

The Annichiarico method was more efficient than ANOVA and the Wricke method (1965) for the adaptability and stability analyses in order to establish a recommendation index of genotypes for favorable and unfavorable environments. Even after considering the small number of evaluated environments, we recommend the genotypes SP78-4764, RB813804, and SP79-1011 for the LN, LS, and MS microregions, respectively.

\section{Conflicts of interest}

The authors declare no conflict of interest

\section{ACKNOWLEDGMENTS}

We gratefully acknowledge the scholarship support to João de Andrade Dutra Filho from the Brazilian institution Coordenação de Aperfeiçoamento de Pessoal de Nível Superior (CAPES). 


\section{REFERENCES}

Amorim EP, Oliveira Camargo CE, Penteado Ferreira Filho AW, Pettinelli Junior A, et al. (2006). Adaptabilidade e estabilidade de linhagens de trigo no estado de São Paulo. Bragantia 65: 575-582.

Annicchiarico P (1992). Cultivar adaptation and recommendation from alfalfa trials in northern Italy. J. Genet. Breed. 46: 269-278.

Bastos IT, Barbosa MHP, Cruz CD, Burniquist WL, et al. (2003). Análise dialélica em clones de cana-de-açúcar. Bragantia 62: 199-206.

Bastos IT, Pereira Barbosa MH, Vilela de Resende MD, Peternelli LA, et al. (2007). Avaliação da interação genótipo x ambiente em cana-de-açúcar via modelos mistos. Pesq. Agropec. Trop. 37: 195-203.

BIOSEV (2013). A Louis Dreyfus Commodities Company. Available at [http://www.biosev.com]. Accessed April 4, 2013.

Bressiani JA, Vencovsky R and Burnquist WL (2002). Interação entre familias de cana-de-açúcar e locais: efeito na resposta esperada com a seleção. Bragantia 61: 1-10.

CONAB (2013). Companhia Nacional de Abastecimento. Available at [http://www.conab.gov.br]. Accessed April 4, 2013

Cruz CD (2006). Programa Genes: Biometria. Editora UFV, Viçosa.

Cruz CD, Regazzi AJ e and Carneiro PCS (2012). Modelos Biométricos Aplicados ao Melhoramento Genético. Editora UFV, 514.

Dutra Filho JA, Melo LJOT, Resende LV, Anunciação Filho CJ, et al. (2011). Aplicação de técnicas multivariadas no estudo da divergência genética em cana-de-açúcar. Rev. Cienc. Agron. 42: 185-192.

Dutra Filho JA, Vilela Resende L, Bastos GQ, Simões Neto DE, et al. (2013). Utilização de marcadores moleculares RAPD e EST's SSR para estudo da variabilidade genética em cana-de-açúcar. Rev. Cienc. Agron. 44: 141-149.

Fernandes AC (2003). Cálculos na agroindústria da cana-de-açúcar. EME, 240.

Koffler NF, Lima JFWF, Lacerda MF, Santana JF, et al. (1986). Caracterização edafo-climática das regiões canavieiras do Brasil: PERNAMBUCO. Editora IAA, 78.

Kumar S, Singh PK, Singh J and Swapna M. (2004). Genotypes x environment interaction analysis for quantitative traits in sugarcane. Indian Sugar 53: 813-818.

Neto JFL, Dutra Filho JA, Neto DES, Silva AEP, et al. (2012). Avaliação agroindustrial e parâmetros genéticos de clones UFRPE de cana-de-açúcar no litoral norte de Pernambuco. Pesq. Agroc. Pernamb. 17: 1-6.

Oliveira JS, Sobrinho FS, Fernandes SBV, Wunsch JA, et al. (2004). Estratificação de ambientes, adaptabilidade e estabilidade de híbridos comerciais de milho para silagem no sul do Brasil. Cienc. Rural. 34: 997-1003.

Rea $R$ and Sousa-Vieira O (2002). Genotype x environment interactions in sugarcane yield trials in the Central-western region of Venezuela. Interciencia 27: 620-624.

Rosse LN, Vencovsky R and Ferreira DF (2002). Comparação de métodos de regressão para avaliar a estabilidade fenotípica em cana-de-açúcar. Pesq. Agropec. Bras. 37: 25-32.

Scott A J and Knott M (1974). A cluster analysis method for grouping means in the analysis of variance. Biometrics 30: 507-512.

Silva e Oliveira J, de Souza Sobrinho F, Vicenci Fernandes SB, Wünsch JA, et al. (2004). Estratificação de ambientes, adaptabilidade e estabilidade de híbridos comerciais de milho para silagem no sul do Brasil. Cienc. Rural. 34: 997-1003.

Silva MA (2008). Interação genótipo x ambiente e estabilidade fenotípica de cana-de-açúcar em ciclo de cana de ano. Bragantia 67: 109-117.

Souza PHN, Bastos GQ, Anunciação Filho CJ, Dutra Filho JA, et al. (2012). Avaliação de genótipos de cana-de-açúcar para início de safra na Microrregião Centro de Pernambuco. Rev. Ceres 59: 427-432.

UNICA (2013). União da Indústria da Cana-de-Açúcar. Available at [http://www.unica.com.br]. Accessed April 4, 2013.

Wricke G (1965). Zurberechnung der ökovalenzbeisommerweizenundhafer. Pflanzenzuchtung 52: 127-138. 